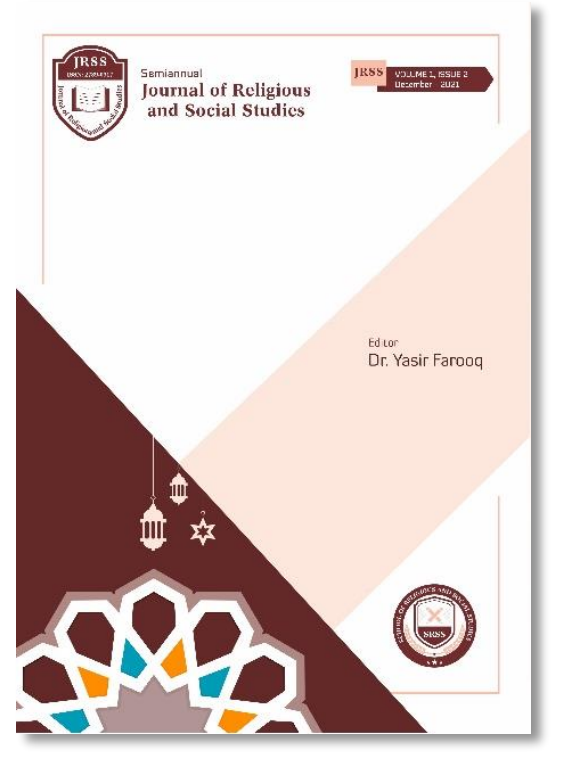

Journal of Religious and Social Studies

http://ejrss.com/index.php/jrss

ISSN (Print): 2789-0317

ISSN (online): 2789-0325

School of Religious and Social Studies,

Faisalabad (38000), Pakistan.

\title{
Impacts of Covid-19 on Religious Seminaries \& Educational Sectors of Pakistan: A Scholastic Approach
}

Sadaf Butt, Saad Jaffar, and Zeenat Haroon

To cite this article:

Butt, Sadaf, Saad Jaffar, and Zeenat haroon. "Impacts of Covid-19 on Religious Seminaries \& Educational Sectors of Pakistan: A Scholastic Approach." Journal of Religious and Social Studies 1, no. 2 (2021): 1-16.

DOI: https:// doi.org/10.53583/jrss01.0102.2021

Published online: 30 September 2021

氙 Submit your article to JRSS

: View this issue

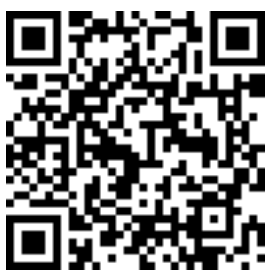

OPEN ACCESS

Full Terms \& Conditions of access and licensing can be found at: http://ejrss.com/index.php/jrss/policies

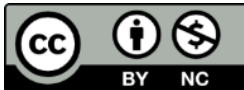




\title{
IMPACTS OF COVID-19 ON RELIGIOUS SEMINARIES \& EDUCATIONAL SECTORS OF PAKISTAN: A SCHOLASTIC APPROACH
}

\author{
Sadaf Butt ${ }^{1}$, Saad Jaffar ${ }^{2}$, and Zeenat Haroon ${ }^{3}$
}

\begin{abstract}
Corona Virus (COVID-19) has become one of the most contagious pandemics of the $21^{\text {st }}$ century, which has affected people all over the world. Economically stable countries have not suffered as much from the crises, but third-world countries are suffering greatly from the virus. Currently, Pakistan is also facing economic, and educational crises, on the other hand, people are losing their lives every day. This pandemic has not only created problems for students but also the government. A staggering economy, growing poverty, and online learning are still huge challenges. Marking strategies during online learning are absent and lack of student's concentration increased the different problems. This research study has been conducting to analyze the impacts of the Corona Virus on Pakistan's education and Religious Seminaries (Madāris) even Mosques are also devastated by the epidemic. The present study is also an attempt to elaborate on all those hurdles which appeared during online learning. This research comprises primary and secondary sources including government and official records, journals and books, etc. intending to find out the reasons for students' dropout rates along with the need for digital education in Pakistan. This study also concludes that lack of training for instructors both non-teaching and teaching and unawareness of the new working methodologies are still the most noticeable challenges.
\end{abstract}

Keywords: Coronavirus, COVID-19, Pakistan, Educational Sectors, Digital Education, Madaris, Religious Seminaries, Online learning.

\footnotetext{
Department of Pakistan Studies, Abbottabad University of Science and Technology, Pakistan. Department of Islamic Studies, Abbottabad University of Science and Technology, Pakistan. Department of Quran and Sunnah, University of Karachi, Karachi, Pakistan.
} 


\section{PRELUDE}

In 2020, the whole world is completely affected by an epidemic Coronavirus which was first identified in the city of Wuhan (China) in December 2019, and later created the most unexpected crises and lockdown in the world. ${ }^{4}$ Officially declared as a pandemic by World Health Organization, this pandemic created huge gaps in the education sector around the world that is an irreparable loss. There has been a huge increase in educational disruptions and educational activities around the world that have been severely affected. Europe and America have not had a problem with online learning but developing countries like Pakistan have faced many difficulties with it. Along with a fragile economy, Pakistan also faced many health problems during this pandemic. during COVID-19, where education and health issues were seen, there is also a significant increase in unemployment. Pakistan GDP growth rate was around $5.8 \%$ in 2018 and now it is $0.98 \%$ and the fiscal deficit is $10 \%$, there are fears of further decline. ${ }^{5}$

"It is reported that about 2.45 million people suffered from food insecurity and balance diet deficiency. In Pakistan's one-third people live under the poverty line while $66 \%$ or 145 million people are living in poverty and needs immediate help and care"

Even with access to basic education in a developing country like Pakistan, education is beyond the reach of many children, 22.8 million of Pakistan's over 70 million children are out of school and this is the second-highest rate in the world. Due to a deadly pandemic like the coronavirus, the faltering economy along issues such as poverty and unemployment problems, educational activities were suspended for six months, which wasted not only the time of students, on the contrary, the lack of digital platforms has affected educational activities. Three hundred thousand schools remained closed in Pakistan from March to September 2020, due to a lack of internet and smartphone facilities, millions of students were deprived of online learning. ${ }^{7}$ Religious educational

\footnotetext{
4 Mehreen Zahra Malik, "The Corona Virus Effect on Pakistan's Digital Divide," BBC Report, July 14, 2020. http:// www.bbc.com/worklife/article/20200713-the-coronaviruseffect-on-pakistans-digital-divide.

$5 \quad$ Ibid

6 "Pakistan National Education Response and Resilience Plan (K-12) for COVID-19," Ministry of Federal Education and Professional Training Government of Pakistan, May 4, 2020. http://mofet.gov.pk. Ibid.
} 
centres and academic institutions also faced the same situations, complete lockdown from March 2020.

Learning is the most basic necessity in human life, which awakens the conscience of humans, normal life was going good but everything was forcibly terminated by the Corona Virus. Many countries closed the academic institutions in an attempt to contain the spread of COVID-19. It was the dark day of $26^{\text {th }}$ February when the first two cases of Coronavirus were reported; within a week Pakistan confirmed three more cases, gradually the number of patients increased. Due to the high spread of the virus by March 15, and schools, colleges, religious seminaries, and universities were closed for an indefinite period. The sudden stop of formal learning badly affected the children, youth, refugees, persons with disabilities, forcibly displaced persons, and those living in rural and urban areas. Some 23.8 million additional children and youth (from pre-primary and tertiary) were added to the dropout list.

\section{CHALLENGES FOR SCHOOL, COLLEGE, AND UNIVERSITY STUDENTS:}

Almost 50 million schools and other educational institutions remained closed due to COVID-19, apart from traditional education; students touched online learning first time, which was a new experience for the student of every level. Schools and colleges in which it was prohibited to keep mobiles, now started opening schools through mobile and internet. The biggest challenge that came up at the beginning was the lack of smartphones and unstable internet, weak internet coverage remained a major problem particularly in remote provinces like Baluchistan, KP, and Gilgit Baltistan. In the world's fifth most populated country, only a small fraction has access to the internet, about $80 \%$ of children stayed away from education due to distance from education. ${ }^{8}$

According to Pakistan Telecommunication Authority (PTA):

"Outside Pakistan's big cities, home broadband is too expensive. Smartphones penetration is $51 \%$ and only one million school-age children have regular access to digital devices and bandwidth" ${ }^{\prime \prime}$

\footnotetext{
8 "Pakistan National Education Response and Resilience Plan (K-12) for COVID-19," http://mofet.gov.pk.

$9 \quad$ "Challenges for Students," Dawn, July 25, 2020. http://www.dawn.com.pk.
} 
Online teaching tools are touching by private schools while on the other side government schools are unaware of e-learning. It was beyond the reach of the government to provide every child with a phone or laptop. The day after the announcement of the closure of schools and colleges, Federal Education Minister announced that online classes would be taken on Television. Distance online classes were released on PTV Home on April 13, and 54 million population has a subscriber base, all courses from grade 1 to 12 were taught and the students watched the government channel for their allocated hour. ${ }^{10}$ Launching classes on television was a successful experience because the TV has a wider reach than digital technology at a moment in Pakistan, but due to heavy load shedding that attempt was not $100 \%$ successful and continuous load shedding prevented students from taking full classes. In an interview with the BBC, the Federal Minister of Education Shafqat Mahmood said:

"We are also now working for launching a radio school so that hopefully some remote areas could be accessed"

Radio schools do not require internet dependency and computers while making use of the existing means of telecommunication. For the radio school, Prime Minister Pakistan Imran Khan announced a "Student Relief Package", in which by reducing the internet packages and duties on smartphones, efforts were made to ensure access to students. ${ }^{11}$ But still, many parents were not able to buy mobile phones for their children, so problems like ten kids, one smartphone kept getting worse. Due to the different classes and different educational material of children and especially lack of mobile space, $90 \%$ of parents were very upset. According to an estimate in Pakistan, about 39.6 million students were affected however Tele-school, $\mathrm{Ta}^{\prime} \mathrm{lim}$ Ghar and many learning apps played an important role in delivering distance learning, but the Tele-school channel was uneven in its quality. ${ }^{12}$ Some programs were incomprehensible and fast-paced, while other broadcast channels were better. Students and parents are also worried about the

\footnotetext{
10 "Pakistan Telecommunication Authority Report," The Nation, August 11, 2020. http://www.thenews.com.pk.

11 Natasha Erumm, "Tele School for Children's Distance Learning Launched," www.pakistanijournal.com. 
schools not reopening, and this anxiety was having a bad effect on their nerves. According to Pakistan National Education Response and Resilience Plan (K-12):

\begin{abstract}
"Permanent closure of educational institutions means a learning deficit for students that will increase the flow between expected school years and adjusted school years and potentially increased dropout rates, deprive children of schools will increase the number. COVID-19 will enhance the existing rural-urban, population, with the potential to increase the prevalence of child labour. The existing situation invokes for a genuine approach to the continuation of learning to address the effects of the recession and its effects on the existing weak education system"13
\end{abstract}

The closer of all academic institutions due to this virus compelled the education system of Pakistan that how to reach the different sources and lens of education. The unprecedented and untested scale of online teaching was also a great challenge for teachers, many tests and assessments were cancelled.

"UNESCO share the report according to which, 87\% student population across the globe is facing school and university closure. 1.5 billion Learners in the world could not attend the academic activities because of the steps taken to reduce or stop the spread and loss from the Corona Virus" ${ }^{14}$

The complete six months of COVID-19 were extremely stressful for students, repeated, postponement and cancellation of exams increased uncertainty, no clear instruction about the cancellation of exams, or when the exams would be held instead, what grading system would be used? On the other hand, constant online classes for 5, 6 days, prolonged exposure to the screens with headphones was not an ideal scenario, all were extremely stressful and led to increases in anxiety and depression. Furthermore, without physical learning students received a lot of depression and unstable mental health, especially eating habits and sleep cycles deteriorated and the constant online classes required them to sit all the time. In those circumstances, students were suffered from great mental stress.

13 The News, May 23, 2020. http://www.thenews.com.pk.

14 "Pakistan National Education Response and Resilience Plan (K-12) for COVID-19," Ministry of Federal Education and Professional Training Government of Pakistan, May 4, 2020. http://mofet.gov.pk. 


\section{MARKING STRATEGIES DURING CORONAVIRUS:}

With the rapid shift from the orthodox classroom to technologically advanced and evolving online learning, internal assessments were badly affected by COVID-19 all over the world. Many countries adopted different strategies for accessing the student's knowledge, as they developed virtual classrooms, practice novel technologies for assigning and submitting homework tasks. In Norway, it was decided that all 10th-grade students will be awarded a high-school degree while in the UK, all the exams for the main public qualifications were cancelled. ${ }^{15}$ In Pakistan, many examinations were postponed or rescheduled, students of private schools used many apps like, zoom, Google classroom, WhatsApp, they attended online classes in which main points were discussed while in higher education, many universities and colleges replaced traditional exams with online assessment tools. ${ }^{16}$ That was a new area for both teachers and students, and assessments likely have larger measurement errors than usual. The careers of this year's university graduates may be severely affected by the COVID-19 pandemic. They experienced major interruptions in their assessments. Average and below-average children's academic performance was severely affected due to the absence of regular assessment tools, while the above-average children managed to balance their performance to some extent.

Google online quiz (Google forms) managed to check the concepts of children, other than that, no other means of marking was seen in the whole six months. Most of the children had such opinion that "We will be upgraded, so what is the use of studying?" This situation was mostly seen in these families, where parents were not well educated. That is why a lot of dropouts in online learning looked up.

"In addition to learning disadvantages, the economic impact on households ids likely to widen inequalities in academic achievement. Experimental evidence shows that children from the poorest families are much likely to complete basic education as well as lower secondary and in Pakistan, this distribution is more than $50 \% " 17$

\footnotetext{
15 "Policy Brief Education During COVID-19 and Beyond," United Nations Report, August 3, 2020. http://www.un.org.

Ibid.

“Disrupted Learning," Dawn, May 9, 2020. http://www.dawn.com.pk.
} 
The education commission did not provide a platform where students could lodge complaints regarding online education so that they could be better reformed. It is true that Students by lack resources or enabling environment accessible to education. Several universities across the world decided against holding open book exams. Students could use the internet or any book while writing the exam. Open book exams force the students to think critically, it would cause them to think and answer. Some exams in Pakistan are cancelled completely like matriculation and FA board exams, students are upgraded and promoted to other classes even below average students also promoted to the next class. ${ }^{18}$

\section{IMPACTS OF COVID-19 ON PAKISTANI EDUCATION}

The Coronavirus has had a devastating effect on education, until now it has been estimated that due to this crisis world's economy would make a difference of 8.5 trillion USD over the next two years. More than 34 million people across the globe would be pushed into extreme crises because of this pandemic. A huge sector that has been impacted greatly by COVID-19, is the education sector. Exams were cancelled and online classes had commenced in private schools, while government school students watched online subjects classes on PTV Home. Parents also demanded relief from school fees while on the other hand schools raised the issue that they do not have money to pay the staff and teachers. ${ }^{19}$

As of June $28^{\text {th }}, 2020$ the data of UNESCO has revealed that there have been nationwide closures of schools and colleges in more than 114 countries across the world, which affected more than 1 billion students. There were very few countries in the world where the schools were not shut down, especially Australia, Sweden, and Greenland. ${ }^{20}$ In Pakistan, more than 46, 803, 407 students have been affected by this pandemic. Some schools stopped teaching entirely while others resorted to online classes. Online classes were a great solution in the short run, but they also created a digital divide. The problem was further exacerbated when several families ran their daily affairs through day-to-day

18 Shehzad Jeeva, "Decision Making on Education around COVID-19," Dawn, May 18, 2020. http://www.dawn.com.pk.

19 Ibid.

20 "Policy Brief Education During COVID-19 and Beyond," United Nations Report, August 20, 2020. http://www.un.org. 
happening, they lost their livelihood after the lockdown. Most of the people in Pakistan have been jumped into poverty due to the demerits of the coronavirus. ${ }^{21}$ The data for the year 2017-18 shows that boys in villages drop out of school midway, the top two reasons behind this are financial constraints in their families and economic work. These two reasons are also applicable as well as in the COVID-19 situation, this means when the school reopens the financially settled families' children go back to schools but poor family's children will not attend the school. They would be pushed into child-labour due to the above-mentioned two problems. The affected students' ratio is alarming in Pakistan and it could be increased if the appropriate steps are not taken.

Affected learners in Pakistan stands at 46, 80,407 reported figure. It will also increase at the pre-primary level are 8,636,383, at secondary to $13,357,618$, and at the tertiary level of about 1,878,101. However, this is not the first time in Pakistan that schools have been closed, many times schools remained closed at the provincial level due to various circumstances for example ago due to smog that gripped most parts of Pakistan. Sadly, millions of children in Pakistan are out of school due to poverty. Pakistan's education system is currently going through a very dangerous situation. Pakistan needs to come up with a better policy to deal with all problems. Coronavirus has brought great difficulty in the field of education, now it's time to prepare at all times to formulate a sound policy to meet all the challenges that lie ahead. ${ }^{22}$

Coronavirus not only had a profound effect on education unavailability and poor internet has hampered the education sector of Pakistan. Internet users in Pakistan are gradually increasing but the offline population lived in rural areas and the major issue is the lack of change from the old feature phones to new smartphones. See Table $1 \& 2$;

\begin{tabular}{|l|l|l|l|l|}
\hline Users & Population & \% Pen. & GDP p.c. & $\begin{array}{l}\text { Usage } \\
\text { Source }\end{array}$ \\
\hline $\mathbf{1 3 3}, \mathbf{9 0 0}$ & $163,985,373$ & $0.1 \%$ & US\$ 490 & $\underline{\text { ITU }}$ \\
\hline $\mathbf{1 2 , 0 0 0 , 0 0 0}$ & $167,806,831$ & $7.2 \%$ & US\$ 821 & $\underline{\text { ITU }}$ \\
\hline $\mathbf{1 8 , 5 0 0 , 0 0 0}$ & $174,578,558$ & $10.6 \%$ & US\$ 1,017 & $\underline{\text { ITU }}$ \\
\hline $\mathbf{1 8 , 5 0 0 , 0 0 0}$ & $177,276,594$ & $10.4 \%$ & US\$ 1,068 & $\underline{\text { ITU }}$ \\
\hline $\mathbf{3 4 , 3 4 2 , 4 0 0}$ & $192,758,348$ & $17.8 \%$ & US\$ 1,500 & $\underline{\text { ITU }}$ \\
\hline $\mathbf{4 4 , 6 0 8 , 0 6 5}$ & $200,813,818$ & $22.2 \%$ & N $/ A$ & $\underline{\text { IWS }}$ \\
\hline
\end{tabular}

21 "Policy Brief Education During COVID-19 and Beyond," United Nations Report, August 20, 2020. http://www.un.org.

22 "The Impact of COVID-19 in Pakistan," The Frontier Post, July 27, 2020. 
Note: Per Capita GDP in US dollars, source: International Monetary Fund

\begin{tabular}{|c|c|c|c|}
\hline YEARS & $\begin{array}{l}\text { Internet Users } \\
\text { in Pakistan }\end{array}$ & $\begin{array}{c}\text { Social Media Users } \\
\text { in Pakistan }\end{array}$ & $\begin{array}{c}\text { Mobile Connections } \\
\text { in Pakistan }\end{array}$ \\
\hline 2020 & 76.38 million & 37.00 million & 164.9 million \\
\hline $\begin{array}{c}\text { Increased } \\
\text { between July } \\
\text { 2019- Jan } 2020\end{array}$ & 11 million & 2.4 million & 9.6 million \\
\hline $\begin{array}{l}\text { Penetration Jan } \\
2020\end{array}$ & $35 \%$ & $17 \%$ & $75 \%$ \\
\hline
\end{tabular}

Source: Digital 2020 Pakistan

Though online learning through the internet was given to students, it lacked one thing which is essential for all children's social and moral training and that is ethics. It is commonly observed that learning is more important than the examination, especially, morality learning should be given at every level and home but our education system mainly focused upon memorizing the concepts, ethics could not be delivered through virtual classrooms, this gap also created negative impacts in the personalities of students.

\section{IMPACTS OF COVID-19 ON RELIGIOUS SEMINARIES OF PAKISTAN}

Islamic seminaries are commonly known as religious seminaries in Pakistan playing a significant role in spreading Islamic and religious knowledge by teaching various subjects such as Tafsir , Hadith, Figh, and Arabic language along with some social subjects like Urdu, Mathematics, and Philosophy. Five religious seminaries boards (Wafāq) are operating different religious seminaries in Pakistan. Religious seminaries are still nongovernmental organizations but have a unique value in three parallel education systems in Pakistan like funded and private schools. Private and public schools teach Islamiat only while religious seminaries cover all aspects of religious education. In religious seminaries, the academic year starts from the month of Shawwāl and continues 
till Rajab or Sha'ban. ${ }^{23}$ Due to this incident, the duration of the religious seminaries academic year has also been reduced and it is also difficult to meet the educational goals. It is worth mentioning that the number of religious seminaries students in Pakistan is much higher than the number of university students. Gatherings in Mosques were also reduced, even during religious festivals of Eidain. Religious scholars remained in contact with the government for the easing of restrictions but the government did not agree to continue educational activities in Mosques and religious seminaries and it remained suspended till the indefinite period. ${ }^{24}$ It was very difficult to deliver the teachings of the Holy Qur'än through online means. Due to which not only the time of the students but also their academic sessions were also wasted. These shortfalls will be filled by giving students short courses at appropriate intervals but it will take time to address the lack of educational activities among religious seminaries students.

\section{A FOCUS ON DISADVANTAGED STUDENTS}

Before the spread of COVID-19, Education Policy Institute reveals that average or below-average students are disadvantaged ones and a half years of learning behind other students. During the pandemic, these students suffered a lot and faced equity gaps. The most disadvantaged students especially adolescents have been disproportionally affected. Pakistan received a grant to fight the negative impacts and effects of the Corona Virus on the education system. Ministry of Education Pakistan tried to increase the federal and provincial coordination and prepared a solid plan to ensure children's safety, especially the most vulnerable, and to ensure learning continuity during the COVID$19^{25}$;

"In May, US\$20 million GPE aid was received by Pakistan to stabilize the regional governments' with ability to rehabilitate from the Corona crisis while addressing upcoming dangers. The GPE grant will be used to facilitate by the World Bank. On the other hand, UNICEF the coordinating agency will handle the work of the local education group to make

Faisal Kammal, “Pakistan's Religious Leaders Defied Corona Virus Mosque Restrictions then Compromised," The Conversation, May, 29, 2020. http://theconversation.com. Ibid.

25 Mariam Ahmed, "Lockdown Students and Brewing Mental Health Crises," Dawn June 11, 2020. http://www.dawn.com.pk. 
sure support from the challenges by COVID-19. UNICEF allocated \$ 140,000 by GPE for the system-level response"26

According to GPE's program, the expected benefits were given to at least 11 million students and teachers, the main focus of this program was to reach the nearly 19 million students who were already out of the school before the COVID-19. ${ }^{27}$ This program is also financing the development of learning materials for children, living in rural and remote areas. Students received learning material including books, home-based assignments, and resources, and it could lessen the equity gaps and improve the achievement gap between disadvantaged and advantaged students. On the other hand, religious seminaries did not receive any finance from this program so the religious seminaries students remained deprived of such facilities.

\section{CONCENTRATION DIFFICULTIES}

Students remained confused during online classes, distance learning provided uncertainty about their studies. Students stared at the computer for many hours; it resulted in fatigue, blurred vision, headache, muscle strain, and psychological problems. Online classes were not even a short time solution for primary school children because young children need social and emotional boundaries with other people and teachers for their positive development. Online classes were also more demanding in terms of time, energy level, and concentration span gradually reduced and time management became a challenging task for children. It is widely observed in a report that students from better-off households spent $30 \%$ more time each day on educational activities than are students from the poorest household. ${ }^{28}$ Similarly, many students missed the online classes due to load shedding and most of them complained about their teacher's inability to understand the predicament. In a report it is stated:

\footnotetext{
26 "Policy Brief Education During COVID-19 and Beyond," United Nations Report, August 2020. http://www.un.org.

$27 \quad$ Ibid.

28 Muhammad Ali Falak, “Online Challenges," Dawn, May 24, 2020. http://www.dawn.com.pk.
} 
"The transition to online learning for teachers and students was rapid. Teachers were also struggling for exploring new avenues. During quarantine, young people suffered from mental health problems and most of the students suffered from anxiety and depression"29

This world has tasted many pandemics but the last time such a situation arose was in 1817 when the Spanish flu struck everything, and millions of people were affected by that epidemic. There is no research on that time to tell how it affected people's mental health? This is still a question but COVID-19 left deep imprints on human's minds, it disturbed the educational, social, economic, and political activities of people's life.

\section{LACK OF TEACHERS TRAINING}

Teachers around the world were not ready on large scale to support learning continuity and adopt new teaching methods and techniques. In that time of crisis, wellrounded and effective teachers training is still needed. In Pakistan teacher's training situation is already fragile, $43 \%$ of school teachers received no formal training.

"Arrangement of teacher training and holding various sessions in which development and blending of diagnostic short methods according to distance learning for different teachinglearning methods providing necessary guidance and community outreach tools and follow-ups to school teachers, including dispersing learning materials and engaging with learners in the community in a variety of ways" 30

In Pakistan still, education is divided into three parallel systems, public schools, religious seminaries, and private schools, they have their specific scheme of studies and curriculum. Private schools do try to train the teachers on modern technologies while religious seminaries mainly follow the old traditional methods and public schools hire those teachers who have B.Ed and M.Ed degrees yet the traditional impressions are inscribed in their minds. Teacher's training of three parallel streams is very necessary for positive learning outcomes. Good teachers training mattes in students learning but

29 "COVID-19 Laid Bare Inequalities in Education," The Express Tribune, September 19, 2020. http://www.theexpresstribune.com.pk. Khalid Taimur Akram, "COVID-19 and the Problem Faced by the Higher Education System in Pakistan," The Islamabad Post, August 26, 2020. http://www.theislamabad.com.pk. 
during COVID-19 and now familiarity with modern technology has become essential for teachers. ${ }^{31}$

Increasing teaching workforce available in every level (school, colleges, university, and religious seminaries) to meet the additional requirements arising from the process of reopening schools; this must be included various options of NCHD's model of Government schools teachers and with the help of partnerships with other stakeholders such as "Teach for Pakistan" to fulfil the requirement of extra teachers.

\section{NEW LEARNING OPPORTUNITIES AND CHALLENGES}

The COVID-19 changed the learning techniques and also the growing need to guarantee the safety of learners. This extraordinary crisis calls for and can provide opportunities for long-term systemic changes that will also stabilize the education system all over the state. An American online learning platform udemy founded in May 2010, which is a huge platform with 50 million students, 57000 instructors, and teaching courses in over 56 languages and engaged in spreading knowledge in Pakistan. Another US-based company that offers school and college-level practice exercises, learning dashboards to teach science, computer, math, history, etc., is Khan Academy which is helping to clear the student's concepts sitting at home. ${ }^{32}$ The world has been shifted from information technology to artificial intelligence. Emerging technologies like nanotechnology, robotics, and metamaterials are now opening up new and creative learning opportunities for developing countries.

A digital platform is launched by the Centre for Economic Research in Pakistan (CERP) to meet the crises of COVID-19. It is extremely challenging to work on digital education in low-resourced areas because the average household in Pakistan has access to at least one smartphone but low-income families who live in rural areas cannot meet and touch the needs of digital learning. With a deplorable rate of poverty, reaching a new learning opportunity in Pakistan seems like a dream. The gap between above-average, average households, and below-average families will widen. To connect education with modern

\footnotetext{
31 "COVID-19 Challenges and Opportunities," The News, April 27, 2020. http://www.thenews.com.pk.

Ibid.
} 
technology, it is very important that digital learning should be available to every child in Pakistan, otherwise, $80 \%$ of children will not be able to meet the challenges of the $21^{\text {st }}$ century.

\section{CONCLUSION}

The Coronavirus, which originated in Wuhan, China eventually forced the whole world to close their educational institutions, developing countries also suspended all educational activities after being affected by the Corona. Almost 188 countries closed their academic institutions; this was indeed an unprecedented situation in the history of education. This epidemic also has had a devastating effect on education in Pakistan, apart from traditional education; this was the first and most difficult step towards digital learning. Students from school, college, religious seminaries, and university faced new challenges, though online learning is not a good alternative to formal education that was the only way to stay connected to education. Islamic seminaries remained passive during COVID-19 because Islamic learning cannot meet their requirements and essentials through online mode. Many apps like Zoom, WhatsApp, Google Classroom, and Microsoft team played an important role in this regard, but in a developing country like Pakistan, the lack of electricity and poor internet is a common occurrence, due to which many students suffered mental disorders especially anxiety and depression. Students from public schools were confined to specific subjects taught on Government Channel PTV Home, but the dropout rate was also surprisingly high, about $80 \%$ of students stayed away from educational activities. Pakistan received a \$20 million grant to meet the challenges of disadvantaged students but marking strategies were a question mark for the educationists because during online learning as such no appropriate device was present for evaluating the student's abilities. Some private schools and universities used Google online quiz and open book exam strategies but all these strategies cannot compete with the formal exams.

Online classes kept the students extremely confused, many children could not take online classes due to power shortage and poor internet. On the other hand, there was a lack of training among teachers; they could not cope with modern technologies. Although this pandemic has changed the whole world for a developing country like Pakistan this is still not possible to connect education with modern technology. Having 
three parallel education systems and a low education budget, academic gaps are increasing day by day, Islamic learning is also affected on a large scale along with formal education. To meet the requirements of the $21^{\text {st }}$ century, Pakistan needs to digitalize its education system and that goal can be achieved when the education budget increases. Access to $4 \mathrm{G}$ internet and electricity should also be ensured to the students. The Corona Virus has taught the lesson that we must now digitalize our education system (public, private, religious seminaries), so Pakistan can compete with the modern world. 


\section{BIBLIOGRAPHY}

Ahmed, Mariam. "Lockdown Students and a Brewing Mental Health Crises," Dawn, June 11, 2020. http://www.dawn.com.pk.

Ali, Muhammad Falak. "Online Challenges", Dawn, May 24, 2020. http://www.dawn.com.pk.

Challenges for Students, Dawn, July 25, 2020. http:// www.dawn.com.pk.

COVID-19 Laid Bare Inequalities in Education, The Express Tribune, September 19, 2020. http://www.theexpresstribune.com.pk

COVID-19 Challenges and Opportunities, The News, April 27, 2020. http://www.thenews.com.

Disrupted Learning, Dawn, May 9, 2020. http://www.dawn.com.pk.

Erumm, Natasha. "Tele School for Children's Distance Learning Launched," www.pakistanijournal.com.

Education Ministry, PTV Sign Agreement to Launch Tele School, Dawn, April 2, 2020. http://www.dawn.com.pk.

Jeeva, Shehzad. "Decision Making on Education around COVID-19," Dawn, May 18, 2020. http://www.dawn.com.pk.

Kammal, Faisal. “Pakistan's Religious Leaders Defied Corona Virus Mosque Restrictions then Compromised," The Conversation, May, 29, 2020. http://theconversation.com.

"Pakistan National Education Response and Resilience Plan (K-12) for COVID-19," Ministry of Federal Education and Professional Training Government of Pakistan, May 4, 2020. http://mofet.gov.pk.

"Pakistan Telecommunication Authority Report," The Nation, August 11, 2020. http://www.thenation.com.pk

"Policy Brief Education During COVID-19 and Beyond," United Nations Report, August 3, 2020. http://www.un.org.

The News, May 23, 2020. http://www.thenews.com.pk.

"The Impact of COVID-19 in Pakistan," The Frontier Post, July 27, 2020. http://www.thefrontierpost.com.pk.

Taimur, Khalid Akram. "COVID-19 and the Problem Faced by the Higher Education System in Pakistan," The Islamabad Post, August 26, 2020. http://www.theislamabad.com.pk.

Zahra, Mehreen Malik. "The Corona Virus Effect on Pakistan's Digital Divide," BBC Report, July 14, 2020. http://www.bbc.com/worklife/article/20200713-thecoronavirus-effect-on-pakistans-digital-divide. 